\title{
Seasonal variations in the trophic structure of phyto- and zooplankton communities in lakes in different trophic states
}

\author{
By H.R. Bürgi, Pia Weber and H. Bachmann \\ Institute for Water Resources and Water Pollution Control, EAWAG, Swiss Federal Institute of Technology, \\ Zürich
}

Manuscript received on 13 December 1985

\begin{abstract}
A number of environmental factors are important in regulating the trophic structure of plankton. Increased nutrient supply results in an explosive development of small algae and herbivorous zooplankton. In the eutrophic lakes (Greifensee, Hallwilersee) several algal community collapses occur cach year as a consequence of the grazing habit of the zooplankton, although only the grazing phase in May/June results in a 'clear water period'. Vertical mixing influences the zooplank ton community by reactivating the resting stages of predatory copepods. Predation phases can only be observed in Lake Lucerne, where the hypolimnion ist deep and aerobic. Welt balanced relationships between the different trophic leveis are restricted to the phases with growth limiting conditions.
\end{abstract}

\section{Introduction}

Although there are a large number of comparable spot-sample investigations of plankton, forming some of the earliest scientific work in the field of limnology, long-term quantitative phytoplankton analyses using space integrated methods and shorter sampling intervals are less common. Such an intense series of plankton samples are a prerequisite for the validification of ecological models in system analyses. This lack of information and the question of the influence of eutrophication on the trophic structure of the phytoplankton led us to investigate the temporal variations in the planktonic biocoenosis and its constituent biomass in lakes with different degrees of trophism. For this comparison, three lakes were selected which contrasted starkly in their circulatory behaviour, and in nutrient content and therefore in their productivity and in the resulting parameters such as oxygen depletion in the hypolimnion:

Type A: Mesotrophic, deep lake without oxygen problems, holomictic (Lake Lucerne, Kreuztrichter).

Type B: Eutrophic with regular oxygen debt in the meta- and hypolimnion with irregular, mostly incomplete turnover in winter (facultative oligomictic) (Hallwilersee). 
Type C: Extreme eutrophic lake with complete oxygen debt towards the end of the stagnation pcriod below $6 \mathrm{~m}$ depth, holomictic (Greifcnsee).

Gencral information about thesc lakcs is available in the OECD Report (1980) [19].

\section{Methods}

This investigation was made possible by the very broad range of analytical data provided monthly by the analytical group of the limnology department in EAWAG. For plankton analyses, shorter sampling intervals (1-2) weeks were necessary as a consequence of the dynamic nature of the biological parameters.

Using the integrated sampler described by Schröder [23], a mixed sample from 0-20 m was collected from several profiles and fixed on the lake with Lugol's iodine. The zooplankton samples were removed from five horizontally distributed positions from the lakc bottom to the surface using a tilt-closing nct [4] and fixed with $4 \%$ formalin (after initial anaesthetization).

\section{Enumeration and identification of the animals}

For identification purposes, separate, live samples were removed and processed under the microscope. The numbers of algae and of smaller protozoa were counted using a cylinder plate chamber according to the method of Utermöhl [24]. $500 \mathrm{ml}$ of the sample in Lugol's iodine was concentrated to a final volume of $50 \mathrm{ml}$ by a careful intermediate enrichment [6], using a $30-\mu \mathrm{m}$ filter and then examined in a cylinder plate chamber as with the algae for microzooplankton (ciliates and rotifers) and for the rarer larger algae.

The biomass was classified into trophic level by means of stereometric formulae [21] from the initially recorded fresh weights (fig. 1-6) or dry weight (conversion factor for algae 0.25 , for zooplankton 0.06 ). The biomass was grouped by systematic and functional similarities. The suitability as a food source for the zooplankton and floatability were used as additional criterion in the assessment of the algae in addition to their systematic similarity.

The following categories were constructed

Nannoplankton, motile Netplankton, motile

Nannoplankton, non-motile Netplankton, non-motile

Algae capable of forming layers (e.g. by means of gas vacuoles) were classified as motile forms. The zooplankton were subdivided into herbivorous and carnivorous microzooplankton, phyllopods and copepods, where the microzooplankton was composed of ciliates, zooflagellates and rotifers. The members of the individual species of each biomass group is shown in the table.

\section{Results}

Several phases can be detected in the phytoplankton dynamics which recur each year. For example, the succcssion in dominance from the nannoplankton in spring to the netplankton in June/July and the sequential appearence of the systematic algal groups starting with cryptophyceae and central diatoms during the early part of the year followed by pennales diatoms, green algae and conjugate algae in high summer and ending with dinophyceae and cyanophyceae in Scptember/Octobcr.

Climatic perturbations leave their mark on the plankton. Although large differences in the concentrations of the major plant nutrients exist (for example, the phosphate content in the highly eutrophic Greifensee was more than an order of magnitude higher than in the mesotrophic Lake Luccrne) the lakes bchave in a similar manncr to long term changes in the wcather situation. During the investigation period (1976), central Europe was characterized by a long term dry spell in carly summer. The hours of sunshinc were considerably higher than the mean from April to the beginning of June and set new records for June, while the rainfall remained well under the norm. Despite the heavy rainfall which occurred in the latter part of the year, such a massive downpour was still insufficient to compensate for the early year deficit.

As a consequence of this deviation from the long term mean, a higher dinophycean biomass was found in both the Greifensee and in Lake Lucerne during the months of August and Septcmber, accompanied by a higher cyanophyte density. The reduccd supply of nutrients during the year probably prevented a higher productivity in the month of July.

In 1979 a large deviation from the long term yearly mean was registered in northern Switzerland. The years mean for the most important meteorological components did not deviate much from the norm because of the oscillations from one extreme to the other which occurred during the course of the year. Several cold air fronts with heavy storms resulted in numerous floods during May, June and July, and the erosion loads associated with these floods were flushed into the waters. As a result of the frequent changes, several pronounced phytoplankton peaks were observed typically with diatoms, dynophyceae and cyanophytes.

The course of the zooplankton development can be followed from the equivalently long generation times of the crustaceans. The exponential development of the herbivorous crustaceans between April and June normally occurs subsequent to a period of self imposed starvation by the animals which, due to their own greed, have themselves reduced the capacity for the production of further nutriment. The large predatory cladocera appears to be strictly periodic in mid summer. The loss of the herbivorous crustacea by predation is, however, sufficient to control their numbers. The summer and winter herbivore maxima (even in the absence of the predatory cladocera) are never able to reach or even approach the peak values found during the clear water period.

The periodicity of the zooplankton appears (as was also found in the study by Einsle on Lake Constance [9]) to be influenced either directly or indirectly (via variations in the nutrient basis) by extreme weather conditions.

Species list of the observed plankton specics in Lake Lucerne, Greifensee and Hallwilersee. Legend: G: Greifensee, H: Hallwilcrsee, L: Lake Lucerne, Na: Nannoplankton. Ne: Netplankton, Mot.: motile, Nonmot.: Nonmotile. Feeding habit: A: algaevorous, D: detritivorous, O: omnivorous, C: carnivorous.

\begin{tabular}{|c|c|c|c|c|c|c|c|c|}
\hline \multirow{2}{*}{ Genera/species } & \multirow{2}{*}{$\begin{array}{l}\text { Volume } \\
\mu^{3} \mathrm{~m}^{3} \text { ind. }\end{array}$} & \multicolumn{3}{|c|}{ Distribution } & \multicolumn{4}{|c|}{ Functional catcgorics } \\
\hline & & $\mathrm{G}$ & $\mathrm{H}$ & L & $\mathrm{Na}$ & $\mathrm{Ne}$ & Mot. & Nonmot. \\
\hline
\end{tabular}

Anabaena flos-aqua

A. solitaria f.planctonica

$\begin{array}{llllll}150 & + & + & + & + & + \\ 450 & + & + & + & + & +\end{array}$




\begin{tabular}{|c|c|c|c|c|c|c|c|c|}
\hline \multirow[t]{2}{*}{ Genera/species } & \multirow{2}{*}{$\begin{array}{l}\text { Volume } \\
\mu \mathrm{m}^{3} / \text { ind. }\end{array}$} & \multicolumn{3}{|c|}{ Distribution } & \multicolumn{4}{|c|}{ Functional categories } \\
\hline & & G & H & $L$ & $\mathrm{Na}$ & $\mathrm{Ne}$ & Mot. & Nonmot. \\
\hline Aphanizomenon flos-aquae $\int$. gracilis & 50 & + & + & & & + & + & \\
\hline A. flos-aquae var. klebahinii & 70 & & & + & & + & + & \\
\hline Aphanocapsa elachissa & 4 & + & & + & + & & + & \\
\hline Aphthothece clathrata var. brevis & 1 & + & & + & + & & + & \\
\hline A. niduluns & 5 & & + & & + & & & + \\
\hline ('Hroococcus limmeticus & 80 & + & & + & + & & & + \\
\hline Coelosphacrium kuet:ingianum & 20 & + & + & + & + & & & + \\
\hline C.minutissimum & 1 & + & & & + & & + & \\
\hline Gomphosphoeria lacustris & 8 & + & & + & + & + & & \\
\hline G. nuegeliama & 20 & + & & & & + & + & \\
\hline Merismopedia sp. & 50 & + & & + & + & & & + \\
\hline Microcystis incerta & 4 & + & & & + & & & + \\
\hline M.aeruginosa & 40 & + & + & + & & + & + & \\
\hline Oscillatoria sp. & 70 & + & & & & + & + & \\
\hline O. rubescens & 70 & & + & + & & + & + & \\
\hline O. obliquaeacuminata & 2 & & & + & + & & & + \\
\hline O. limnetica & 5 & + & + & + & + & & & + \\
\hline Phormidium mucicola & 3 & + & + & + & & + & + & \\
\hline Pseudoanabaena catenata & 7 & & + & + & + & & & + \\
\hline
\end{tabular}

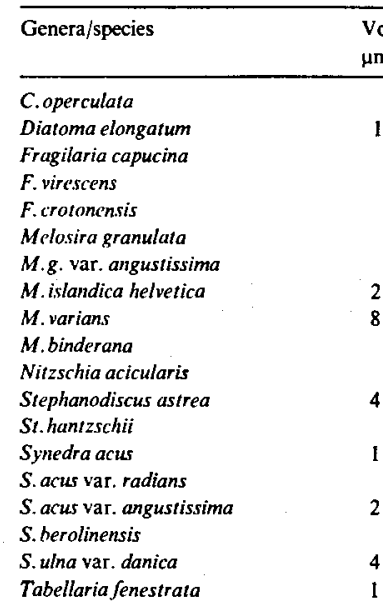

\section{Chrysophyta}

\section{Chrysophyceae}

Bitrichia chodatii

Chromulina sp.

Chrrysococcus sp.

\section{Dinobryon sociale
D. divergens}

D. divergens

Erkenia subaequiciliata

Heterochromonas sp.

Kephyriopsis entzii

Mallomonas caudata

M. akrokomos

M. akrokomos
M. acaroides

M. acaroides

M.elongata

M.producta

Pseudopedinella erkensis

Pseudopeditiella
Stenokaly $x$ sp.

Uroglena sp.

Bacillariophyceae

Asterionella formosa with

Salpingoec a frequentissima

Cyclorella comta

C. catenata

C.kützingiana

C.kützingian
C.comensis

C.comensis

C. sociatis

C. ghemerata

$\begin{array}{rllllll}250 & & & + & + & + & \\ 150 & & & + & + & & + \\ 600 & & & + & + & & + \\ 550 & & + & + & & + & + \\ 550 & + & + & + & & + & + \\ 550 & & & + & & + & + \\ 25 & + & + & + & + & & + \\ 60 & + & + & + & + & & + \\ 250 & + & & + & + & & + \\ 3200 & & & + & & + & + \\ 1400 & & + & & + & & + \\ 1300 & + & + & + & + & & + \\ 3500 & & & + & & + & + \\ 3800 & & + & & & + & + \\ 200 & + & & + & + & & + \\ 550 & & + & + & + & & + \\ 100 & + & + & + & + & & + \\ 140 & + & + & + & & + & +\end{array}$

Haptophyceae

Chrysochromulina parva

\section{Pyrrhophyta}

Dinophyceae

Ceratium hirundinella

Amphidinium turicense

Peridinium cinctum

P. willei

P.pusillum
P. inconspicu

Peridiniopsis polonicum

Gymnodinium lantzsch

G. helveticum

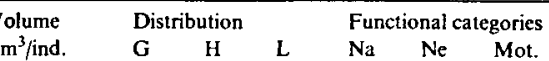

Nonmot.

$\begin{array}{rllllll}350 & & + & + & + & & + \\ 1100 & & + & + & & + & + \\ 200 & & + & + & & + & + \\ 400 & & & + & & + & + \\ 700 & + & + & + & & + & + \\ 800 & + & & & & + & + \\ 250 & + & + & & & + & + \\ 2400 & & + & + & & + & + \\ 8000 & & & + & & + & + \\ 800 & & + & + & & + & + \\ 150 & + & & + & + & & + \\ 4500 & & + & + & + & & + \\ 70 & + & + & + & + & & + \\ 1000 & + & + & + & & + & + \\ 200 & & + & + & & + & + \\ 2400 & & + & + & & + & + \\ 200 & & & + & + & & + \\ 4800 & & & + & & + & + \\ 1700 & & & + & & + & +\end{array}$

\section{Cryptophyta}

Cryptophyceae

Cryptomonas ovata

C.erosa
C. reflexa

C.marsoni

C. tetrapyrenoidosa

Rhedomonas lacustris

Rh.mintua var. nannoplanctica

Rh.lens

Katablepharis ovalis

40

Chlorophyta

Prasinophyceae

Platymonas cordiformis

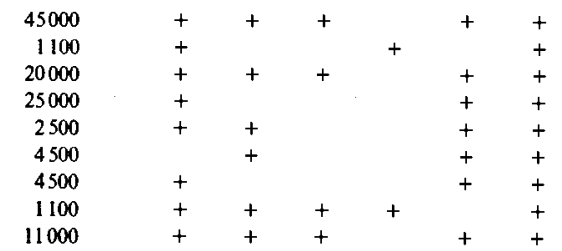

11000 


\begin{tabular}{|c|c|c|c|c|c|c|c|}
\hline \multirow{2}{*}{ Genera species } & \multirow{2}{*}{$\begin{array}{l}\text { Dry weight } \\
\mu g \text { /ind. }\end{array}$} & \multicolumn{3}{|c|}{ Distribution } & \multicolumn{3}{|c|}{ Feeding habit } \\
\hline & & G & $\mathrm{H}$ & $L$ & $\mathrm{~A} / \mathrm{D}$ & 0 & C \\
\hline Conochilus tmicornis & 0.024 & + & & + & + & & \\
\hline Euchlanis dilatatat & 0.014 & + & & & + & & \\
\hline Filinia tomgiseta & 0.032 & & & + & + & & \\
\hline F. Jerminalis & 0.03 & & + & & + & & \\
\hline Gustropus stylifor & 0.007 & & & + & + & & \\
\hline Kellicottia longispina & 0.012 & + & + & + & + & & \\
\hline Keratella cochlearis & 0.004 & + & + & + & + & & \\
\hline K.quadrata & 0.005 & + & + & + & + & & \\
\hline Notholca squamuls & 0.035 & t & & & + & & \\
\hline Plo'soma trancata & 0.015 & & & + & + & & \\
\hline Pompholy:x stckata & 0.014 & + & + & + & + & & \\
\hline Polyarthra dolichoptera & 0.012 & + & + & + & + & & \\
\hline P. major & 0.020 & & + & & + & & \\
\hline P.remata & 0.009 & & + & & + & & \\
\hline P. rulgaris & 0.014 & + & & + & + & & \\
\hline Stnchaeta kitina & 0.012 & & + & + & & + & \\
\hline S.stylata & 0.060 & & + & & & + & \\
\hline S.pectinata & 0.065 & + & & + & & + & \\
\hline S.grandis & 0.09 & & & + & & + & \\
\hline S. oblonga & 0.04 & & & + & & + & \\
\hline Trichocerca similis & 0.008 & & + & + & + & & \\
\hline T.rousselet i & 0.006 & & + & + & + & & \\
\hline T.porcellus & 0.007 & + & & + & + & & \\
\hline T.capucina & 0.011 & & & + & & + & \\
\hline \multicolumn{8}{|l|}{ Crustacea } \\
\hline \multirow[t]{2}{*}{ Diaphanosona brachyurum } & juv. $: 2.0$ & + & & & + & & \\
\hline & ad.: 4.5 & + & & & + & & \\
\hline Eubosmina coregoni & juv.: 2.1 & + & & & + & & \\
\hline Bosmina longirostris & ad.: 3.9 & + & & + & + & & \\
\hline Daphnia hyulina & juv. 9.0 & + & + & + & + & & \\
\hline D. galeata & ad.: 30.0 & + & + & + & + & & \\
\hline D. cucullata & & & & + & + & & \\
\hline \multirow[t]{2}{*}{ Bythòtrephes longimunus } & juv.: 24.0 & & + & + & & & + \\
\hline & ad.: 120 & & + & + & & & + \\
\hline \multirow[t]{2}{*}{ Lepfodera kindiii } & juv.: 90 & + & + & + & & & + \\
\hline & ad.: 480 & + & + & + & & & + \\
\hline Crclops vicinus & $q$ ad.: 6.0 & + & + & + & & & + \\
\hline C.abyssorum & qad.: 6.9 & + & + & + & & & + \\
\hline C. hohater & ? ad.: 24.0 & & & + & & & + \\
\hline Mesocyclops leuckarti & Fad.: 2.1 & + & + & + & & & + \\
\hline Megacyclops gigas & fad.: 150 & & & + & & & + \\
\hline Nauplien mean & 0.15 & + & + & + & & + & \\
\hline Cyctops Cl C3 mean & 1.20 & + & + & + & & + & \\
\hline Cyclops C4 C5 mean & 3.6 & + & + & + & & & + \\
\hline Cjeclops ad is & 4.0 & + & + & + & & & + \\
\hline & 0.8 & + & + & + & & + & \\
\hline \multirow{2}{*}{ Eudiaptomus gracilis } & juv.: 1.1 & + & + & + & + & & \\
\hline & ad. $: 2.8$ & + & + & + & + & & \\
\hline \multirow{2}{*}{ Mixodiaptomus laciniatus } & juv.: 1.1 & & & + & + & & \\
\hline & ad.: $\mathbf{3 . 0}$ & & & + & + & & \\
\hline
\end{tabular}

The most important biomass groups are, in Lake Lucerne, the diatoms and the cyanophytes (fig. 1), and in Greifensee, the cryptophyceae, dinophyceae and chlorophyceae (fig. 4). Amongst the zooplankton, the herbivorous phyllopods (especially Daphnia sp.) as well as the omnivorous and carnivorous copepods were particularly prominent. The predatory phyllopods were generally completely absent in the highly eutrophic lake, but were consistently found in the mesotrophic lake in summer. The microzooplankton (protozoan and rotifers) follow the r-strategy, and are able, due to their short generation times, to propagate at any instance. However, the crustacea, whose developmental behaviour involves an interrupted cycle, are thus unable to use this readily available nutrient source. The peaks in the microzooplankton populations appear generally before or after the crustacean maxima (fig. 2, 5).

In mesotrophic lakes, the proportion of the nannoplankton composed of approximately equal numbers of nonmobile (e.g. central diatoms) and mobile (e.g. Rhodomonas) species, is very much lower than in the highly eutrophic lakes (fig. 3,6 ). In such lakes, the plankton is dominated by these nannoplankton during the period between October and May. The netplankton appear, partly as a result of the selective grazing of the zooplankton, after the clear water stage in June/July. Their predominance occurs only for a short time in the mesotrophic lake, and their numbers are more or less insignificant by September. They are composed in general, of dinophyceae, and cyanophyceae although under mesotrophic conditions there is also a high biomass of pennate diatoms during the main vcgetation period.

The composition of the plankton was determined on the basis of functional criteria (instead of pure systematic trends) taking into account the numerous results in the literature which detail the range and means of exploitation of food resources especially with respect to the growth characteristics of the consumer organisms. In general, four methods have been applied to investigate the choice of food:

1. Live microscopic observation and investigation of the gut contents [1,25, etc.].

2. Limnocorral experiments, with and without zooplankton $[3,11,20$, etc.].

3. Feeding experiments partly with differently marked food or artificial spheres $[5,10,12$, $13,14,16]$.

4. Statistical analysis of the population dynamics of plank ton series [7]

The structure of the planktonic biomass on the basis of its trophic relationships - which will be referred to as 'trophic structure' - considers the position in the food chain and the mechanism of food uptake.

In figures 7-9 the algae are distributed into three major categories, ultraplankton, nannoplankton and netplankton. The groupings of the individual species are shown in the table. The herbivore level is split into the microzooplankton (protozoa and rotifers),

'filtering' crustacea and grasping crustacea. Whilst some rotifers ean live partly as carnivores and others as detrivores, the proportion of this species is shown shifted in the vertical axis of the trophic pyramid. The herbivorous crustacea consists of all species with the exceptions of the predatory cladocerae (Bythotrephes and Leptodera) and the cyclopoides (from the stage $\mathrm{C4}$ ). The latter live as predators on the herbivorous phyllopods and copepods and even on their own progeny. The tip of the planktonic biomass pyramid is composed of the predatory cladocera and chaoborus larvae. The nutrient spectrum of these organisms is composed of all the other crustacea 


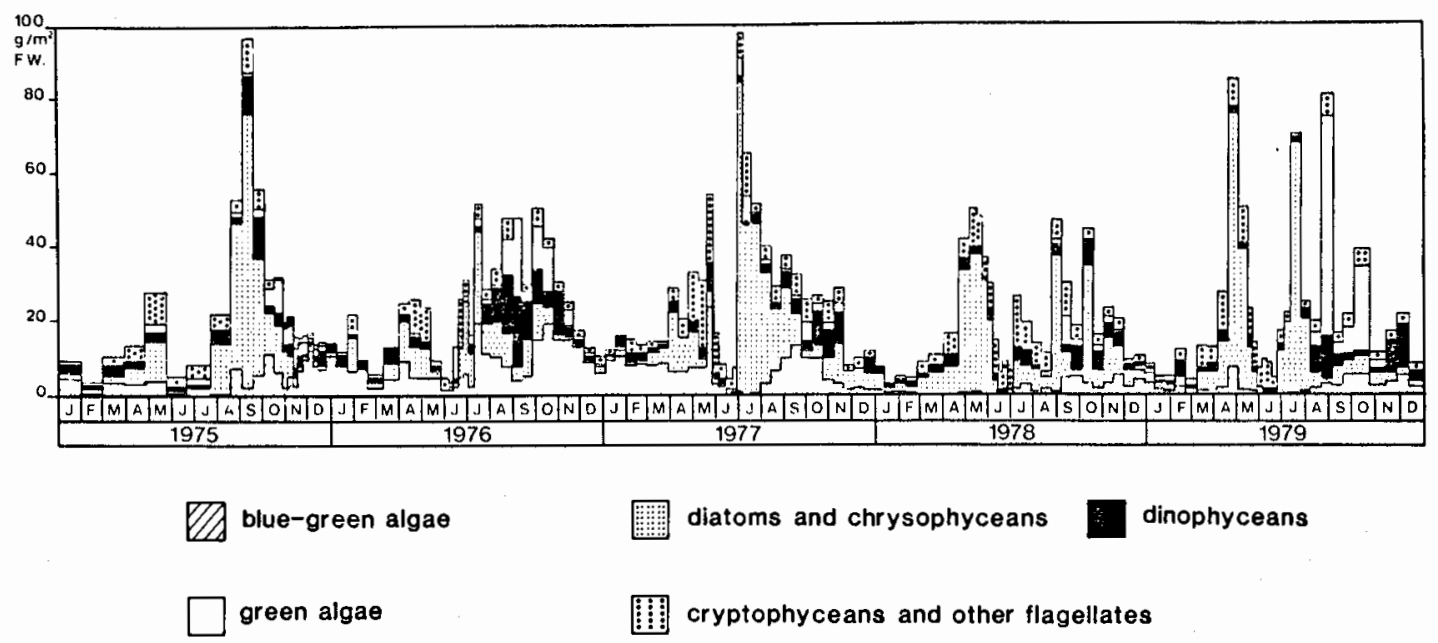

Figure 1. Phytoplankton biomass - dynamics in Lake Lucerne (in $\mathrm{g}$ fresh weight/ $\mathrm{m}^{2}$ ).

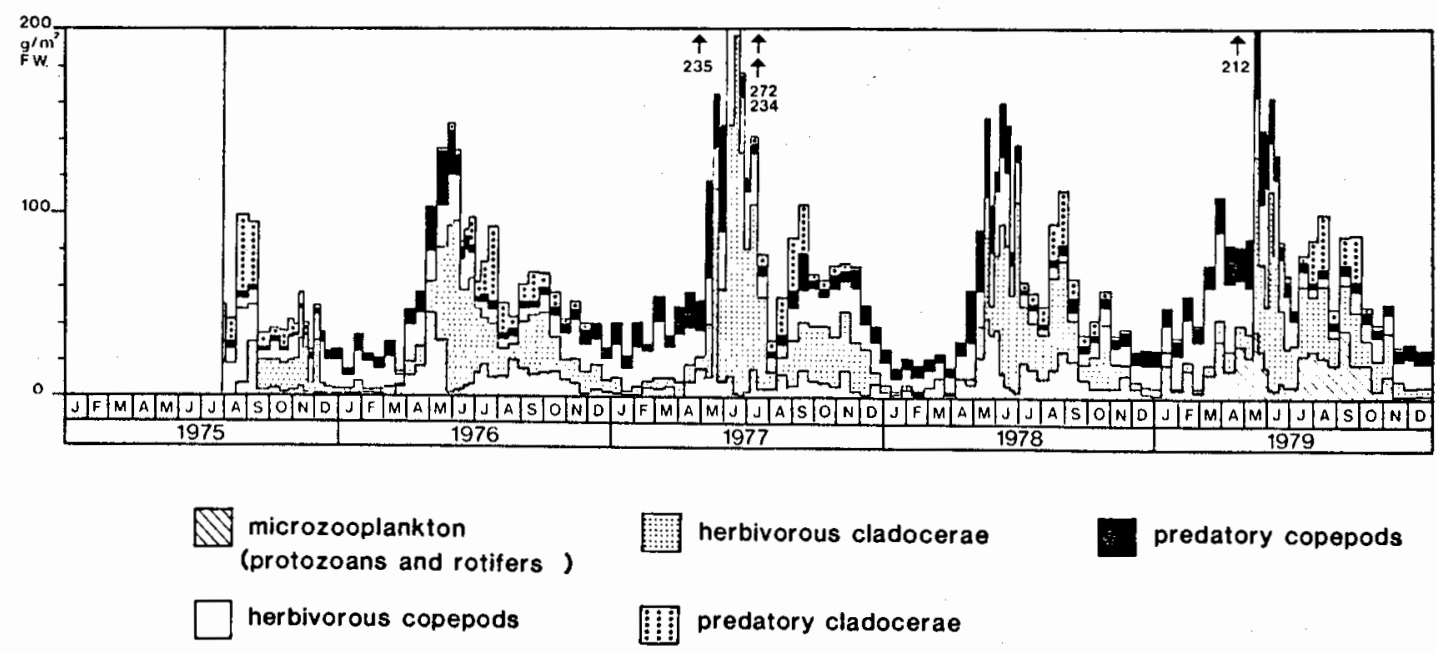




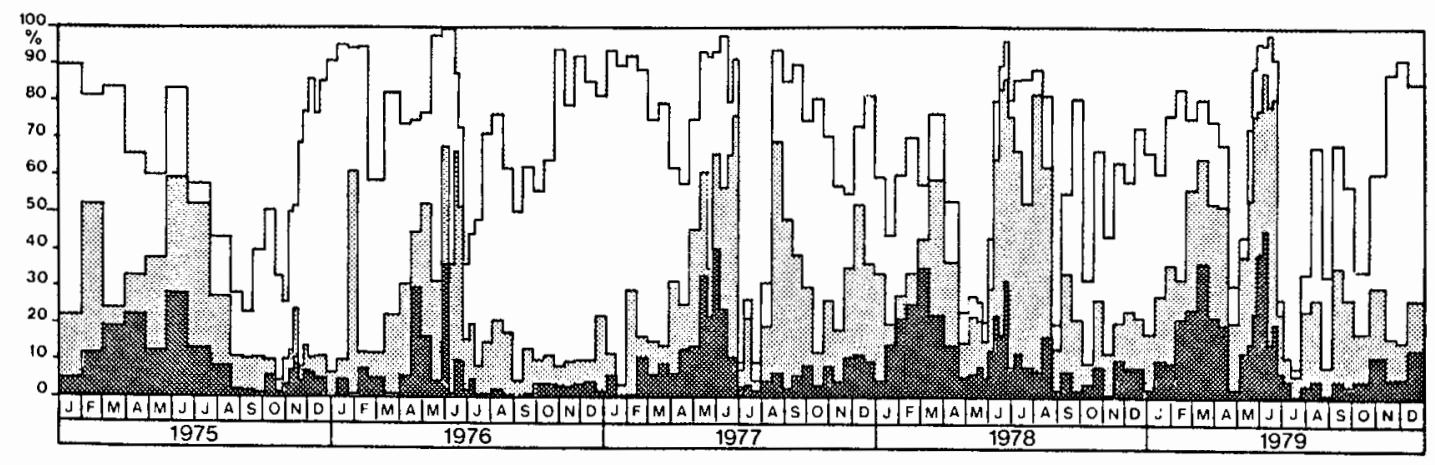

motile nannoplankton $\square$ non-motile nannoplankton $\square$ motile netplankton

Figure 3. Relative proportions of the important functional phytoplankton groups in Lake Lucerne.

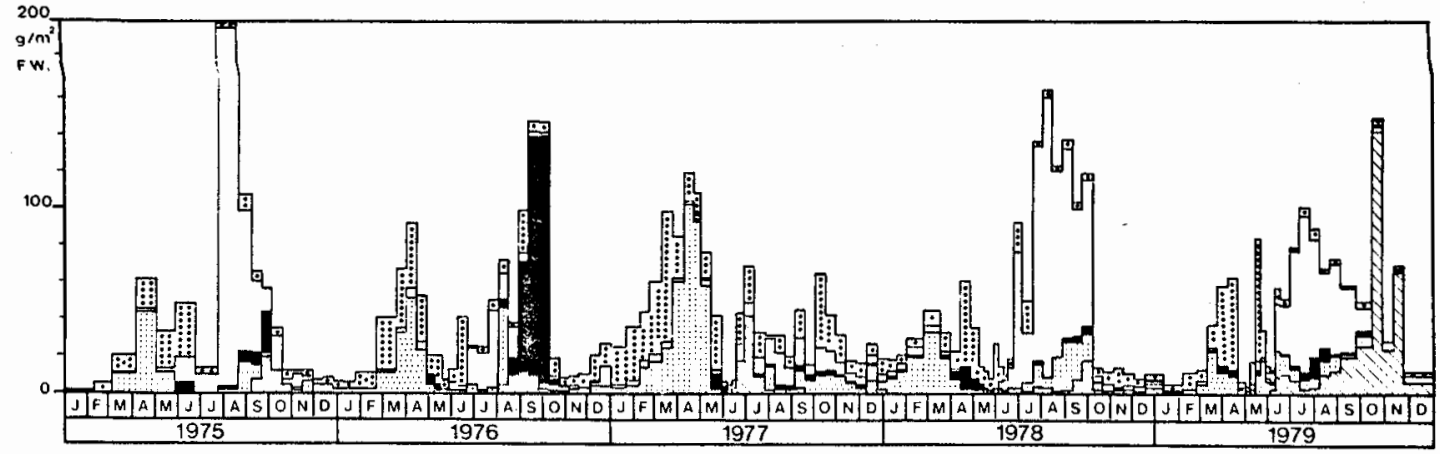

blue-green algae

diatoms and chrysophyceans

dinophyceans

green algae

cryptophyceans and other flagellates 


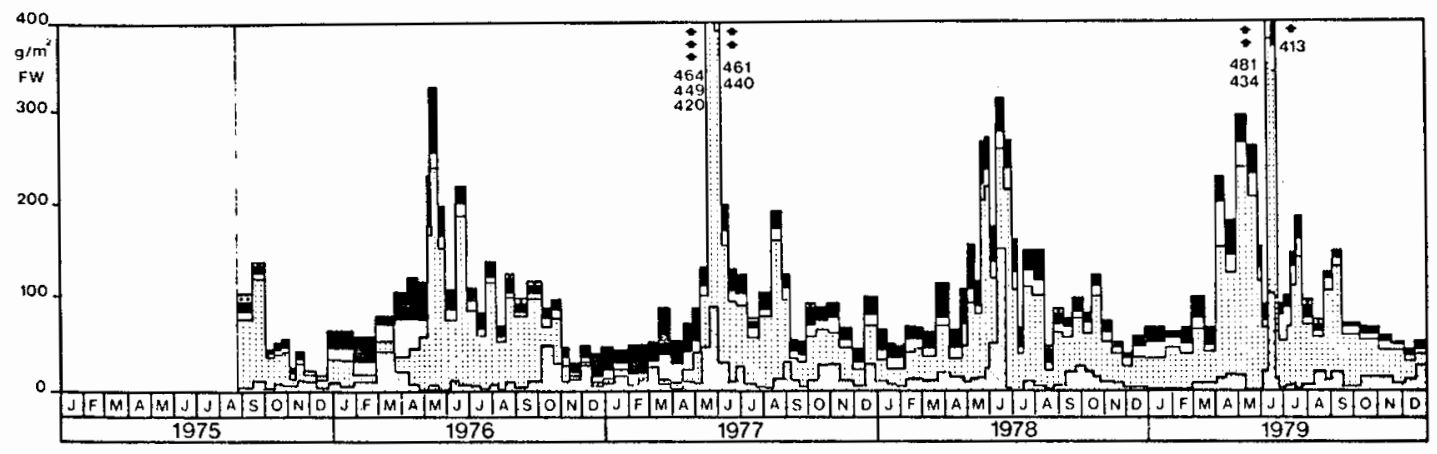

microzooplankton

(protozoans and rotifers)

herbivorous copepods herbivorous cladocerae

predatory cladocerae

Figure 5. Zooplankton biomass - dynamics in Lake Greifensee (in $\mathrm{g} / \mathrm{m}^{2}$ fresh weight).

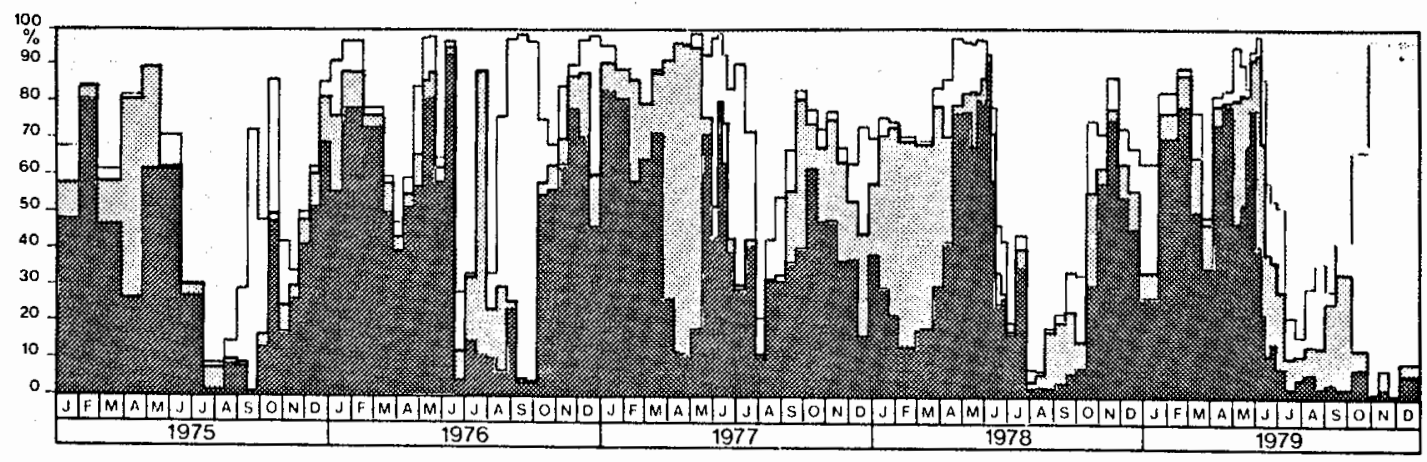


The annual mean of these trophic stages follow lake specific patterns which hardly alter in the long term. Using dry weight as the basis for comparing the three lake types, relatively sharp pyramids result in which each subsequently higher food stage contains less biomass. When the biomass fresh weight is used in place of the dry weight, the proportion of consumers inereases (as a result of the higher content of water per unit dry weight) to three to four fold that of the fresh weight of the primary producers. The trophic structure then represents the incomplete biomass pyramid described by Margelef [15] under marine conditions. In mesotrophic lakes, the biomass pyramid is steeper than in the eutrophic lake, the proportion of carnivores is, with $11-12 \%$ of the total biomass, up to three times as high as in eutrophic lakes. A comparison of the carnivores in class II (predatory cladocera) shows much greater differences. In highly eutrophic lakes, this level is almost completely absent, despite the availability of an adequate food supply.

In the eutrophic Hallwilersee the predatory cladocera did indeed attain a higher individual density, although the population density of the cyclops species was very much lower than that found in the mesotrophic and in the highly eutrophic lake. To what extent these differences had to do with ecofactors specific to the biotope, such as interaction within the biocoenosis, remains to be seen. While the lakes differed considerably in their circulatory behaviour as well as in the oxygen content (as a result of gross differences in productivity and in the extent of the hypolimnion) a relationship to these factors is conccivable. It is possible that in the irregularly mixing eutrophic Hallwilersee, no activation of the dormant juvenile stages of cyclops occurs. A relationship appears to exist between oxygen levels and the length of dormancy [8]. The number of cyclops-copepods which rise from the lake bottom increases in proportion to the amount of lake sediment which is reached by the winter turnover and thercby supplied with oxygen [17]. In the highly eutrophie Greifensee the preferred habitat for the Bytrotrephes is probably not present in summer when the layer with oxygen is restricted to the uppermost $4-5 \mathrm{~m}$.

The relative proportions of the different biomass groups in the average annual biomass misleadingly implies a long-term equilibrium. If the analysis data is represented in half monthly steps, a much more complex regrouping would result in the plankton structure (with the exception of during the unproductive winter time). In figures 10-12 the rapid rearrangement of the trophic structures in the three different lake types for particular years is shown. The similarly large individual values for winter, spring and autumn, are expressed as their seasonal means. In detail, the following deductions can be made.

In the early part of the year, the r-strategists (small fast-growing forms) increase in number, the magnitude of the algal biomass being initially determined by the light requirement of the individual algae and subsequently by the nutrient content (after of the turnover period). An acceleration in the zooplankton development occurs during the first half of May and with it the start of the grazing period. Initially there is a predator-prey relationship amongst the microzooplankton, in which, during the rapid propagation of the herbivorous forms a phase occurs with Asplanc/ma as the dominant form.

The rigidly photoperiodically controlled behaviour of $C$. vicinus, which migrates from the pelagic zone and goes into a dormant phase in the sediment as soon as it reaches the 4th copepod stage, and as soon as the light part of the day excecds 15 hours, prevents this predatory generation from using the wide nutrient basis formed by the herbivorous crustacea. These will thus be spared from further predatory loss and can carry on their progressive growth. Since other regulatory factors are absent (e.g. no territorial activity)

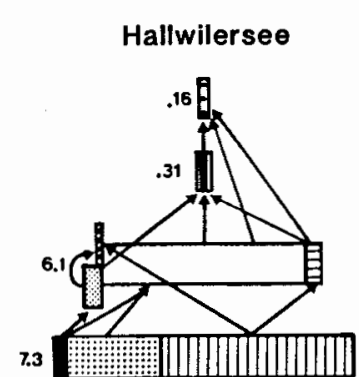

predatory cladocerae

琎 predatory copepods

$\square$ herbivarous cladocerae

是 orasping rotifers

圈 nerbivorous copepods

Q tiltering ciliates and rotifere

대. netplankton

nannoplankton

uttrapleankton

Figure 7. Annual average of the plankton biomass from the different trophic levels in Lake Hallwilersee $\left(\mathrm{jn} \mathrm{g} / \mathrm{m}^{2}\right.$ dry weight). The arrows indicate the most important food fluxes.

this development is completed only when the primary production level is filtered out by overgrazing to a fraction of the earlier biomass. This phase occurs mostly at the beginning of June and is manifested as the clear water stage.

The parthenogenetic propagation cycle of the Daphmia is succeeded after the starvation phase, by the first peak in the dicyclical appearance of the bisexual propagation form and is indicated by the appearance of Ephippien. Further growth peaks in the nannoplankton are not reacted to, since the potential users are now absent.

In July/August the large predatory cladocera (Bythotrephes and Leptodera) reached their devclopmental maximum and become the means of control of the rcmaining crustacea. This predatory phase leads to a significant loss in biomass although the composition of the phytoplankton at this time corresponds to the nutritional requirements of the herbivorous crustacea. Depending on the climatic conditions, a slight development of Daphinia occurs again, which then react to the changed phytoplankton composition (dominated by the poorly utilizable blue-green algae) with a second bisexual reproduction phase. As opposed to the observations of zooplankton in Lake Constance $[9,18]$ this second build up of Ephippien only reaches its maxima in Lake Lucerne, in November/December.

The course of development in the highly eutrophic Greifensee (fig. 11) and in the eutrophic Hallwilersee (fig. 12) are much more hectic and peak with more extreme maxima than in the mesotrophic Lake Lucerne. In the Greifensee. development of rotifers in May/June was particularly noticeable. At the time when the Daphinia change to the bisexual reproductive form but were still under the influence of the starvation phase (clear water period) the major fraction of the biomass consisted initially of herbivores and then in quick succession of carnivorous rotifers. Still in July, the herbivorous crustaceae were again active for one to two further grazing phases such that the reduction in the algal biomass was unable to reach the minimal values of the month of June.

There were no further grazing periods during the summer in these two lakes, despite the 


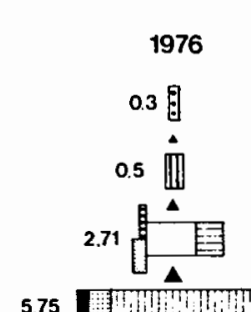

Vierwaldstattersee - Plankton 1977

5.75

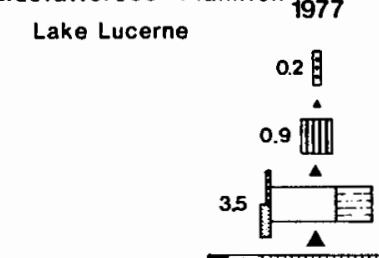

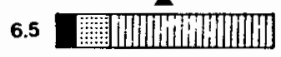
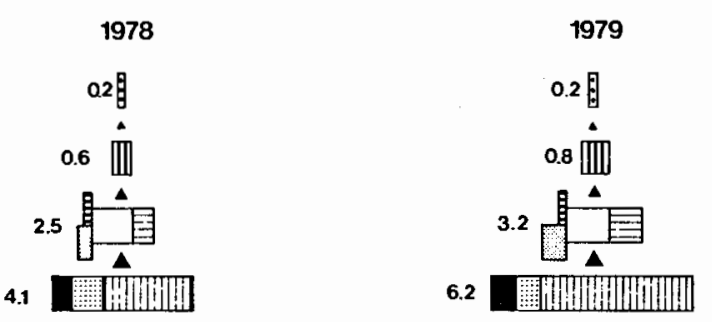

Figure 8. The annula average of ptankton biomass from the different trophic levels in Lake Lucerne (Vierwaldstättersee) in $\mathrm{g} / \mathbf{m}^{2} \mathbf{d r y}$ weight. Same pattern as in figure 7.
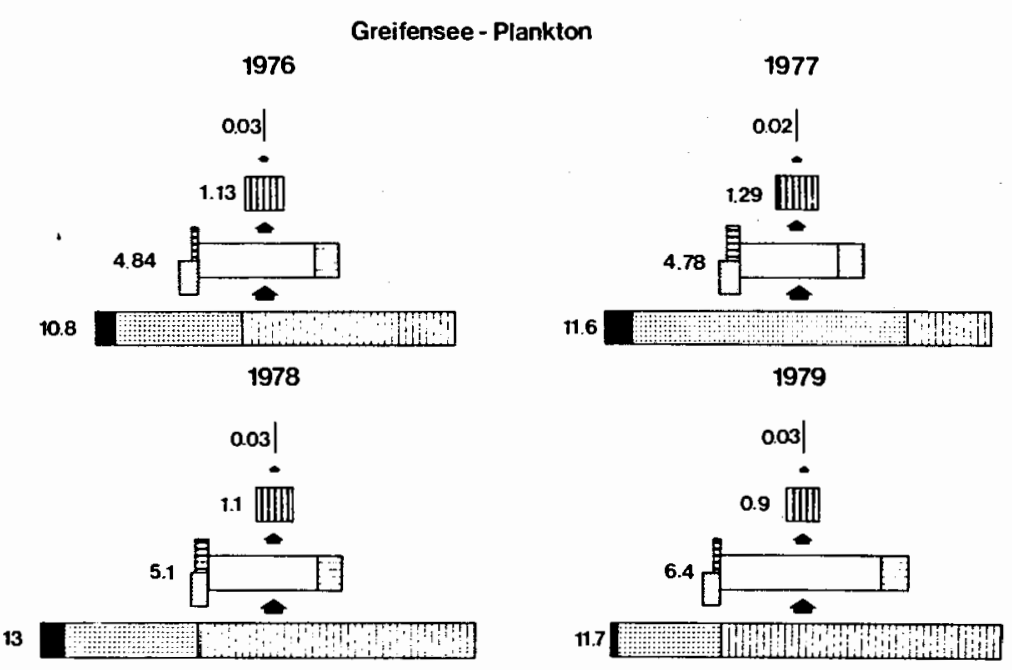

Figure 9. Annual average of plank ton biomass from the diferent trophic levels in Lake Greifensee. The numbers represent $\mathrm{g} / \mathrm{m}^{2}$ dry weight.

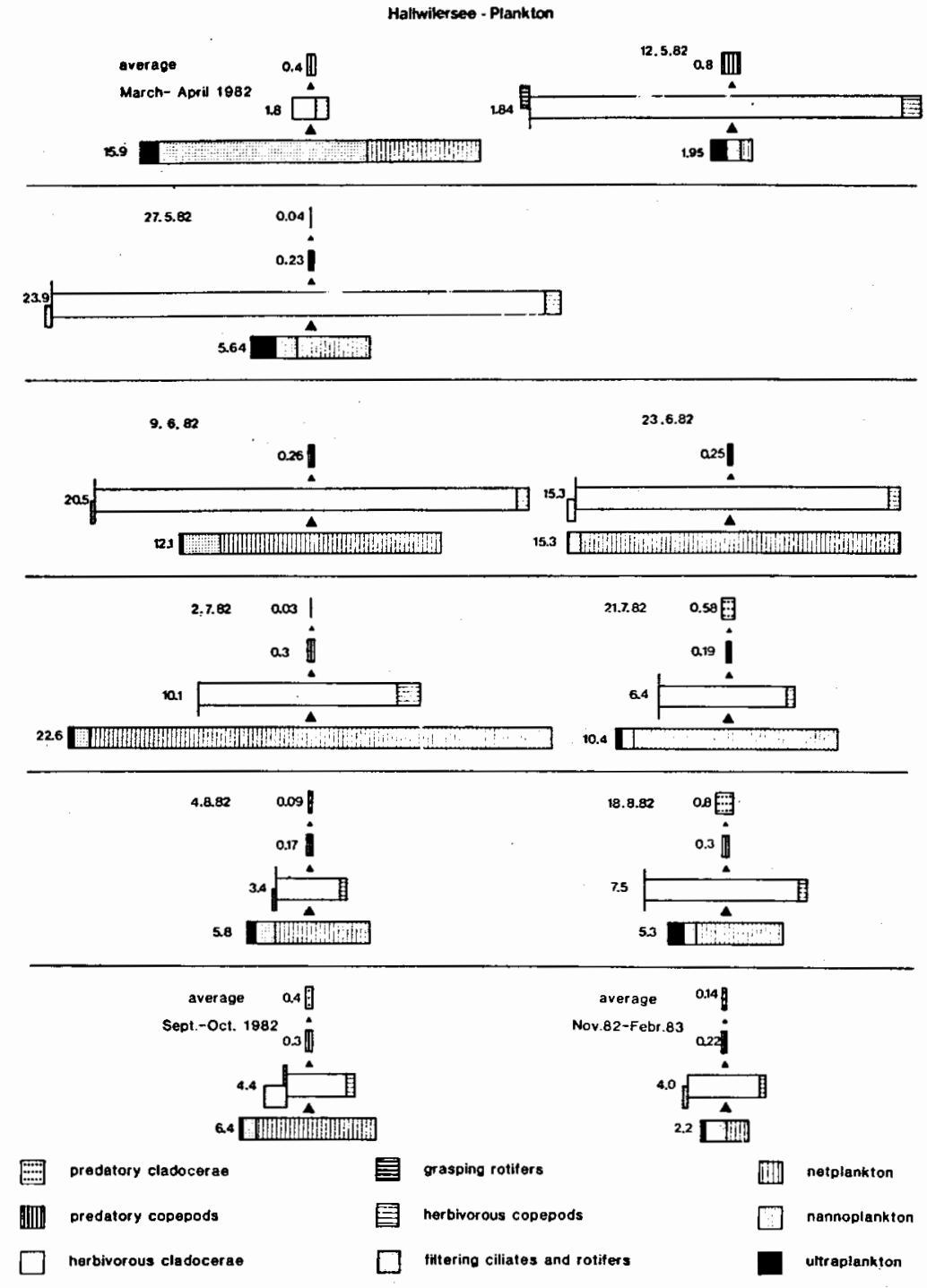

Figure 10. Selected annual course of development in the trophic structure in Lake Hallwilersee (in $\mathrm{g} / \mathrm{m}^{2} \mathrm{dry}$ weight). 


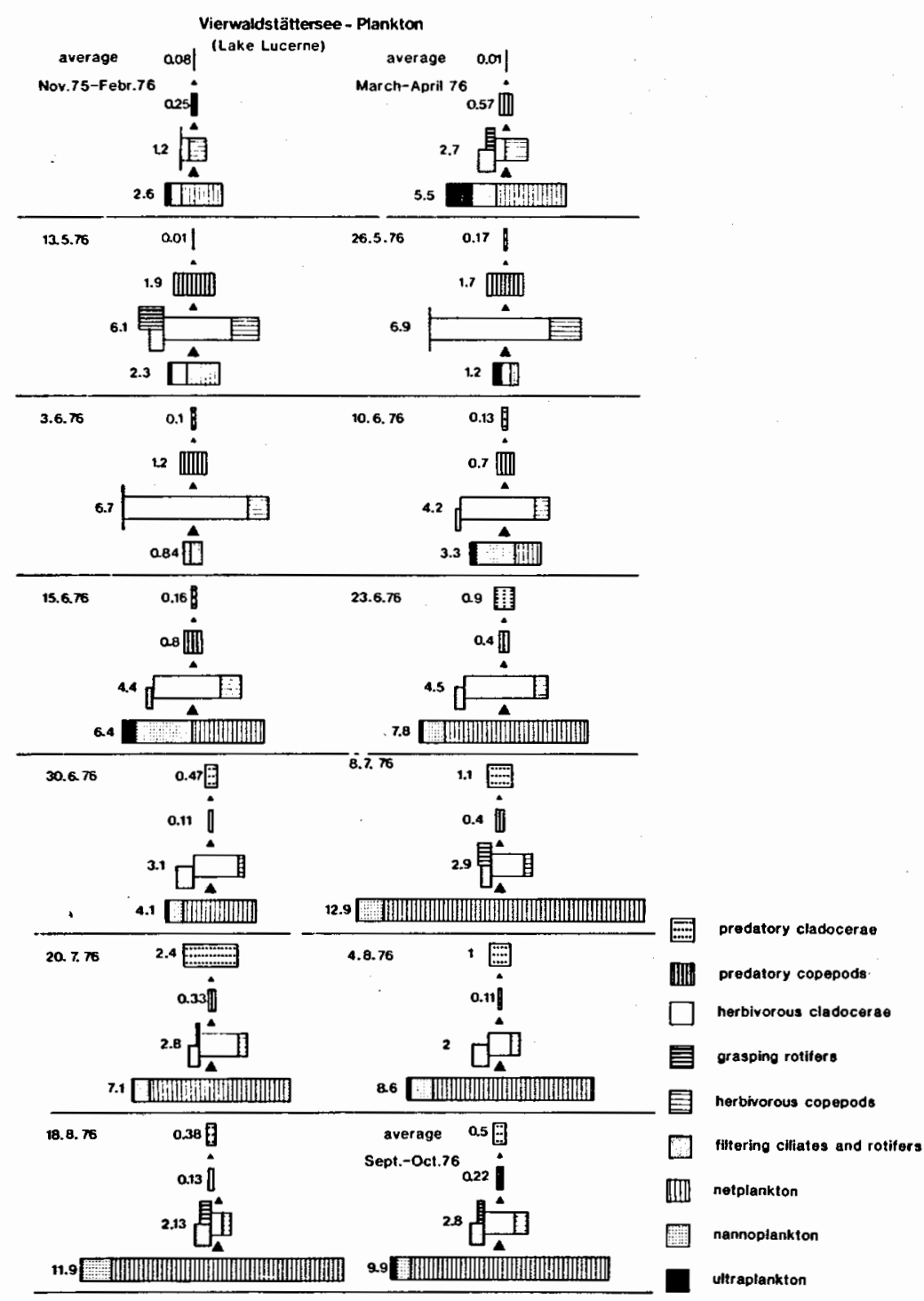

Figure 11. Selected annual course of development in the trophic structure in Lake Lucerne (in $\mathrm{g} / \mathrm{m}^{2} \mathrm{dry}$ weight).

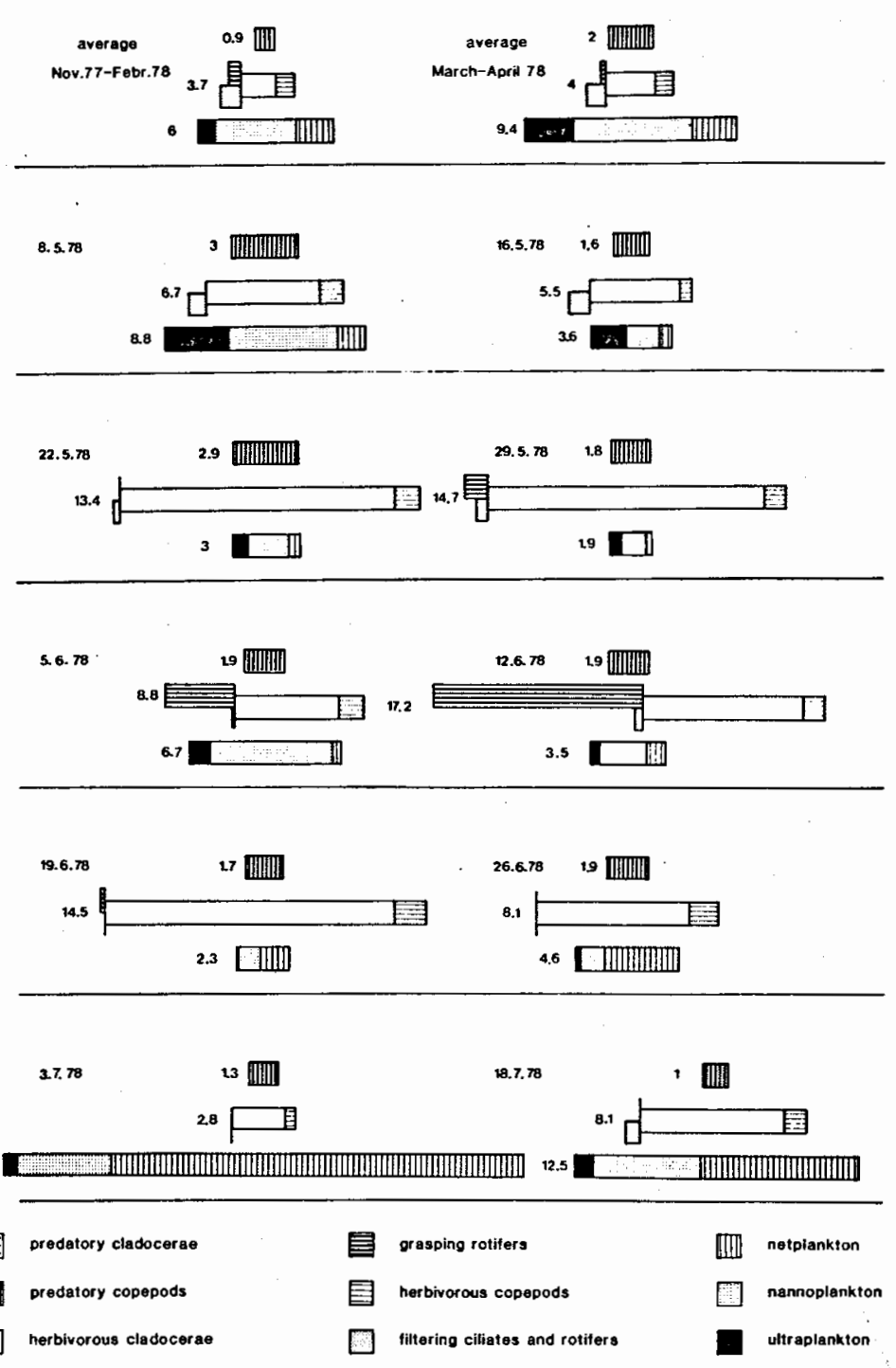

Figure 12. Selected annual course of development in the trophic structure in Lake Greifensee (in $\mathrm{g}^{\prime} \mathbf{m}^{2} \mathrm{dry}$ weight). Part 1. 
2.8.78

$1.7 \mathrm{monm}$

64

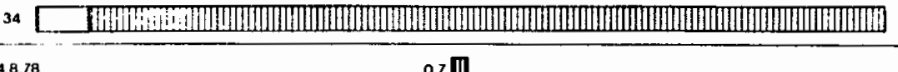

$14.8,78$

0.7 II

$2.1 \backsim$

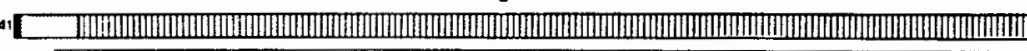

\begin{tabular}{ll}
\hline 28.8 .78 & 0.24 目 \\
& 0.5 国
\end{tabular}

Q5 制

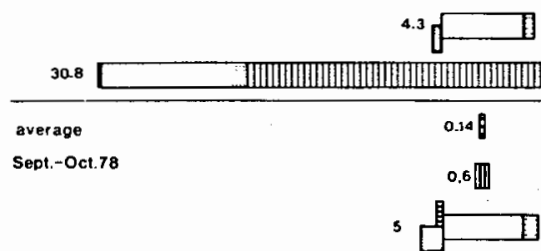

23.3 $\square$

Figure 12. Selected annual course of development in the trophic structure in Lake Greifensee (in $\mathrm{g} / \mathrm{m}^{2} \mathrm{dry}$ weight). Part II.

possibility of this occurring due to the low density of planktonic predators. The reason for this may be, that the phytoplankton biocoenosis in this phase was increasingly dominated by net plankton which were less suitable as food for the herbivorous crustacea. Associated factors, such as light and temperature are responsible interactions along with the zooplankton for this sequence. Anyway, the nannoplankton rapidly increased in biomass in limnocorrals in which the crustaceen biomass was removed, while in limnocorrals with larger zooplankton, netplankton (large algae) appeared $[2,3]$.

This phase-shifted development is clearly shown in the triangular coordinate diagrams (fig. 13, 14). This mode of representation which is normally chosen for the characterization of mixed substances from three components or for ecograms [22], allows a large amount of information to be assembled in one point. The position of the points shows the relative proportion of the individual components (here, algae, herbivorous and carnivorous zooplankton), the size of the points is an indication of the absolute total content $(100 \%)$.

In order to make the changes in the carnivores, which often only reached $10.20 \%$ of the total biomass, clearer, the scale of the carnivores is logarithmic. Therefore, the form of the triangular coordinates deviate from their normal type. The values are however plotted in the normal way and their sum is equivalent to $100 \%$.

As in figures 10-12, phases with small gradients are represented as mean values so as not to complicate the graphics. Details of the trophic structure (e.g. dividing the herbivores into copepods and phyllopods, etc.) had to be omitted so as not to obscure the important
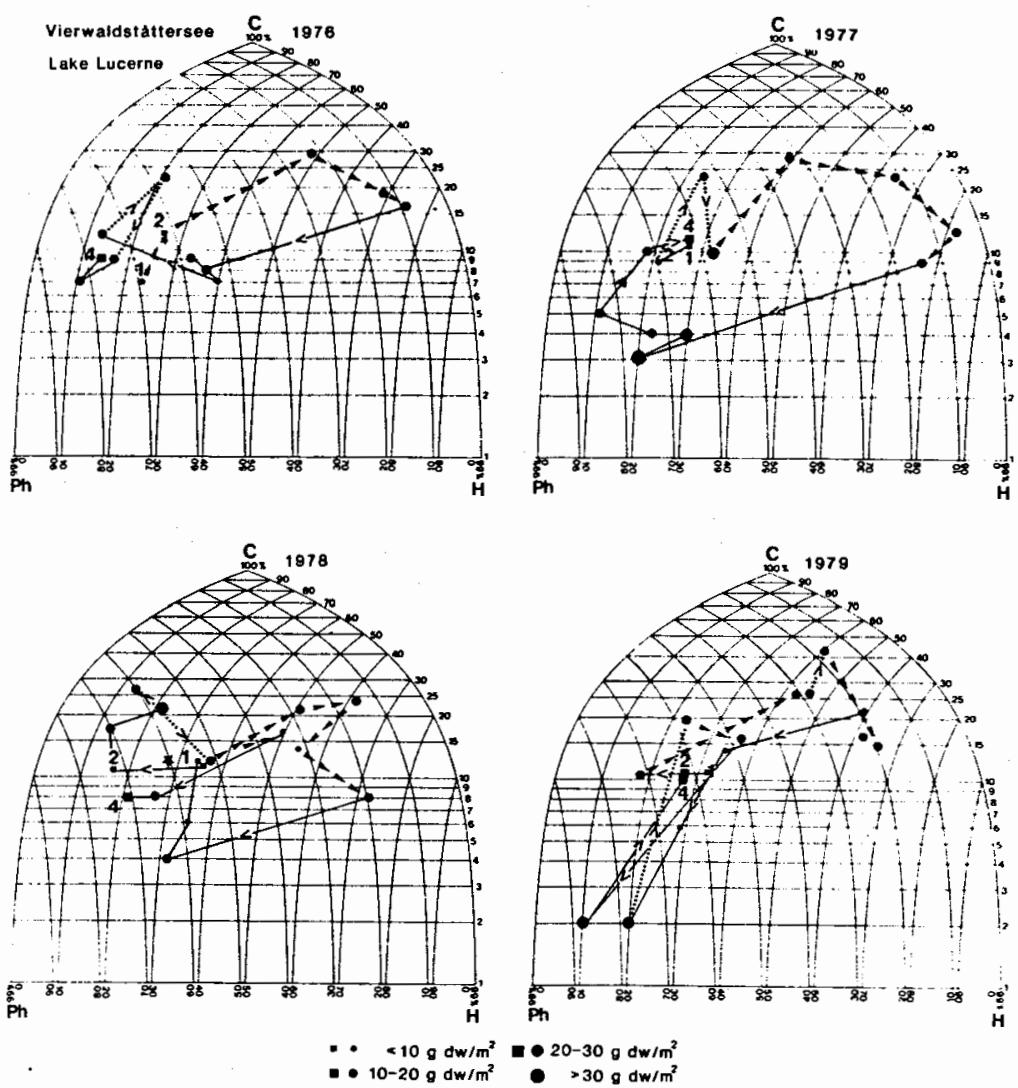

Figure 13. Alterations in the trophic structure during the years 1976.1979 in Lake Lucerne (Vierwaldstättersec). Square symbols with numbers represent seasonal means: $1=$ November February, 2 = March $-A$ pril, 3 = Scptember-October. Asterisks represent annual means. Arrows indicate drastic grazing phases; dotted lines mark predation phases. Ph. H.C stand for the axis of the triangular coordinates: $\mathrm{Ph}=$ phytoptankton. $\mathbf{H}=$ herbivorous zooplankton, $\mathbf{C}=$ carnivorous zooplank ton. The size of the symbols is a representative of the absolute value $(100 \%)$ in $\mathrm{g}^{\prime} \cdot \mathrm{I}^{2}$ dry weight.

points. The grazing and predatory phases (shown by arrows/dotted lines) can now be clearly seen.

In order to emphasize the relationship between the size of the absolute biomass and the relative position within the percentage triangular representation, every single value for each lake is plotted in a synoptic survey (fig. 15). From this. it is clear that the largest biomass values occur at extreme biocoenosis compositions. This tendency suggests that with increasing production (as judged by eutrophication and environmental factors during the course of the year) greater inequilibrium would result. The primary produc- 

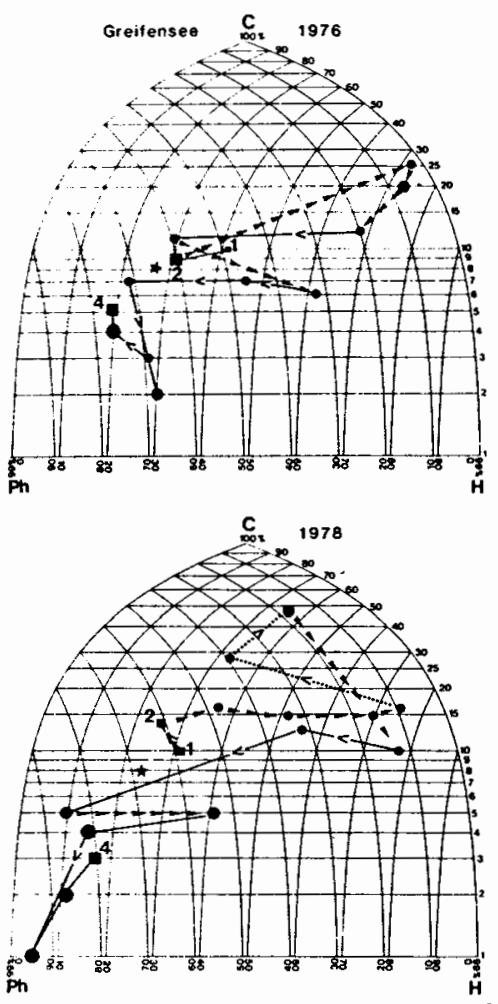

$\therefore<10 g d w / m^{2}$

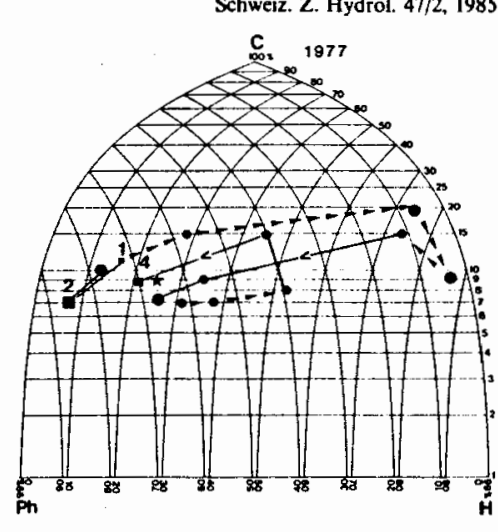

C. 1979

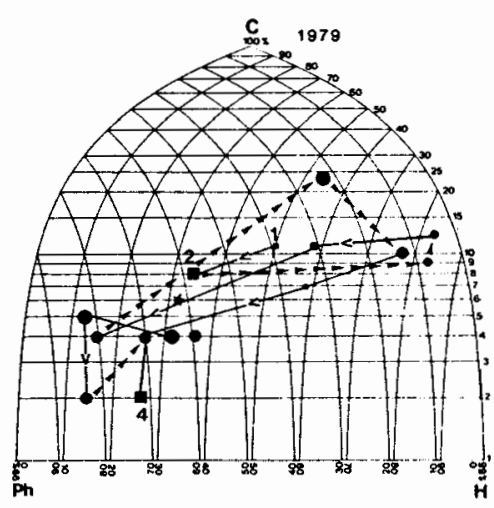

$\underbrace{20-30 \mathrm{~g} \mathrm{~d} / \mathrm{m}^{2}}$

(The same symbols and numbers as in fig. 13.)

tion will no longer be controlled solely by the nutrient basis but now inereasingly through the delivery of nutrients and through the feeding pressures by the relative predators. The different generation times of the different plankton species are responsible for the phase shifts. The smaller the food basis, the more strictly limited is the build up of the trophic pyramid from the base upwards.

The high absolute values with scemingly high \% fractions seen in the diagram can be explained by the fact that the transfer from one extreme to another passes via a stage when all the forms are present at an equivalently high biomass. This composition is however only momentary since the changeover from one state to another occurs very fast. The high biomass values at the edge of the graph also show that the gradients of the temporal changes are very much greater when each of the partners are present in largc numbers. This has the consequence, that when one form becomes dominant a quiet period follows.

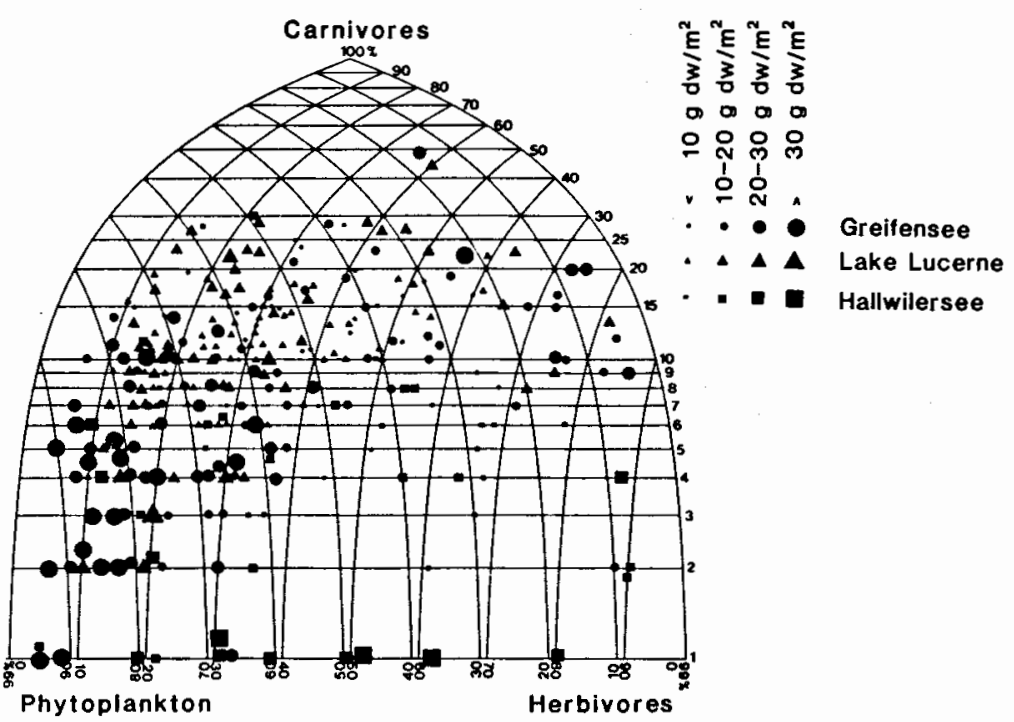

Summary

Dense series of plankton samples were taken in various eutrophic lakes at weekly to bimonthly intervals and analyzed for their seasonal variations. The mean annual biomass reveals lake-specific patterns in the trophic structure which hardly alter during the long term. The eutrophic influence can be more readily seen during the periods of massive algal growth in the summer months than from the values for the mean annual biomass, which are similar despite greatly differing nutrient supplies: $8.3-11.2 \mathrm{~g} / \mathrm{m}^{2}$ dry weight (DW) in a mesotrophic, $13.8 \mathrm{~g} \mathrm{DW} / \mathrm{m}^{2}$ in a eutrophic and $17.1-19.3 \mathrm{~g} \mathrm{DW} / \mathrm{m}^{2}$ in a highly eutrophic lake.

Under eutrophic conditions two to three overgrazing phases per year occurred, while in the mesotrophic Lake Lucerne only one overgrazing period of phytoplankton was detected. Actual collapse of the algal biomass causing the so-called 'clear water stage' was observed only in May/June. Since a high biomass of predatory crustacea was present in Lake Lucerne, distinct 'predation phases' were observed. As with the overgrazing phases, regeneration of the herbivore population was not possible despite good production conditions. In the deep aerobic Lake Lucerne, the carnivorous planktonic populations amount to $11-12 \%$ of the total biomass, while only $6-9 \%$ (mainly $C y c l o p s$ specics which are reactivated from the $\mathrm{C} 4$ diapause stadium by the regularly recurring complete vertical mixing in winter) was measured in the shallow $32 \mathrm{~m}$ deep Greifensee. However, in the $45 \mathrm{~m}$ deep Hallwilersee the carnivores contribute only $3 \%$ to the total annual biomass although the aerobic layer is larger than in the highly eutrophic Greifensce. The reason for this difference is probably due to incomplete winter turnover. 
The investigated lakes differed less in their species composition as in the predominance of individual functional groups. The eutrophic lake contained a higher fraction of nannoplankton and herbivorous crustaceae coinpared with the mesotrophic Lake Lucerne. As a result of biological interactions (e.g. size selective grazing), there was a succession from small algae with a high growth rate (r-selection) in spring to netplankton, which are stabilized around the carrying capacity (K-selection) during the summer.

\section{Conclusions}

The nutrient content of a lake is directly (or indirectly by the expansion of the aerobic habitat) reflected by the typical pattern of the trophic structure of the plankton. Climatic anomalies can help to bring certain species into dominance and thereby affect the annua sequence, without inducing any long term changes in the species composition. In the investigated lakes (Greifensee, Hallwilersee and Lake Lucerne) the maximal algal development is normally attained in summer, whilst the dynamics of the zooplankton with considerable regularity are characterized by a massive development of the herbivorous crustacea in May/June resulting in the so-called 'clear water stage' in June due to excessive overgrazing. The biomass of carnivorous planktonic populations and consequently the significance of predation within the higher trophic level is dependent on the depth of the aerobic habitat and on the circulation pattern of the lake. Therefore it will be of interest to study the effects of artificially improving the turnover during winter in Hallwilersee on the density of predadory copepods.

As the conditions for the plankton improve, the trophic structure shifts such that at any instant any one of the individual components can dominate. A large biomass is only found when one of the components (algae, herbivores or canivores) is more or less absent. Equivalent and long-term stable relationships are prevalent during unproductive periods.

\section{ZUSAMMENFASSUNG}

Dichte Planktonserien mit wöchentlichen bis halbmonatlichen Probenahmeintervallen aus dem Vierwaldstättersee, dem Greifensee (vom Herbst 1975 bis Beginn 1980) und dem Hallwilersee (März 1982 bis Mai 1983) wurden im see, dem Greifensee (vom Herbst 1975 bis Reginn 1980) und dem Hallwilersee (März 1982
Hinblick auf die Veränderungen der trophischen Struktur im Jahresveriaut analysiert.

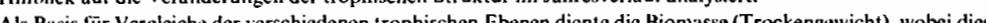
Als Basis fur Vergeleiche der verschicdenen trophischen Ebenen diente dic Biomasse (Trockengewicht), wobei dicse durch Umrechnen der Zahldaten aus quantitativen mikroskopischen Analysen mittels Volumina- und Gewichtsfaktoren gewonnen wurdc. Dic Zusammenfassung der Pla nker in die trophisehen Gruppen erfonge nach funk nellen und sy. (on). dic Zooplankler in Ktit.

Die Biumasse-Jahresmittel zeigen seenspedifische Muster der trophischen Struktur mit geringen Schwankungen (1) (1) ges trion 24. $32 \%$ in Ger zeigl sich her in Anzhl und Hohe der in Welche in Anbech der grossen Un 13,8 . Trekkcngench in Wier.

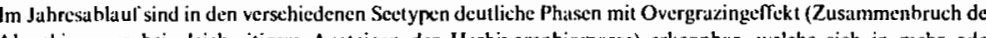

solche "Grazingphase» regelmässig, während in den eutrophen Scen zwei bis drei solcher Übernutzungen des Phyloplunktons uufteten, wobei aber nur dic "Grazinphase" Mai-Juni zum totalen Zusammenbruch der Phytoplanktonbiomasse führt.

Dic Abweidetätigkeit des Zooplanktons verstārkt die Sukzession, welche von $\mathrm{r}$-Strategen (kleine, schnellwüchsige Formen) im Frühjiahr zu K-Strate gen (erössere Formen mit längerer Generationszeit und hesserer Verwertung der Nährstofreserven) im Sommer (ührt. Die selektive Beverzugung kleiner Algen als Futserquele begïnstigt die Nährstoffreserven) im Sommer fuhrt. Die selektive Bevorzugung kleiner Algen als

"Predationsphasen», welche (analog zu den «Grazingphasen ») durch eine Zunahme der Räuber bei gleiehzeitigem - nicht durch Mangelernährung bedingten - Verlust an Herbivoren gekennzeichnet sind, treten nur ausnazhms weise auf, z. B. im Juli im Vierwaldstäticrsee. Im Greifensec kommt es im Mai zu einem kurfristigen Maximum aüuberischer Rotatorien ( Asplanc/ima) welche sich von Mikrozooplank Main und erösseren Alènen ern̈̈hren können. räuberischer Rotatorien ( Asplanc/ina), welche sich von Mikrozooplankton und grösseren Algen ernihren konnen. kleinc Reste versehwinden. Das Zwergptankton kann sich daher kurzfristig erholen, bevor es dann durch cine weiterc Entfaltung der herbivoren Cladoceren erneut zusammenbricht.

Für die Entwicklung der Raubcladoceren spielt dic Nahrungsgrundlage eine geringe Rolle. Sie sind vorwiegend durch Ökofaktoren ihres Lebensraumes beeinflusst. Sauerstoffarme oder anoxische Wasserschichten eimen schlecht als Lebensraum. Aus diesem Grunde fehlen Bythorrephes und Leptodora im Greifensee fase voltstandig. schlech al Lebnik der räberischen Copepoden (C) Wechselwirkungen. Ihr Versehwinden im April hängt mit endogenen Verhaltensweisen zusammen, welche bestimmte Larvenstadien (z. B. C4 bei C. vicinus) veranlassen, im Sediment eine Ruhephase (Diapause) einzuscealten. Während der Beginn dieser Diapause durch die Tagcslänge ausgelöst wird, ist die Beendigung vom Wechsel ten. Wahrend der Beginn diese Zirkulation gekoppelt. Die relativ geringen und stark schwankenden Bestände an räubcrischen Copepoden im Zirkulation gekoppelt. Die relativ geringen uürften in der variabien, oft unvollständigen Zirkulation dieses Sees begründet licgen.

Der Vergleich der Gesamtbiomasse und der relativen Ausgewogenheit der trophischen Stufen zeigt, dass grosse Biomassen mit einseitiger Zusammensetzung der Lebensgemeinschaften korrelieren. Auspewogenheit herrscht nur in unproduktiven Zeiten, wenn die Nahrungskette extrem vom Nachschub von der Basis abhängt.

\section{ACKNOWLEDGMENTS}

We would like to express our appreciation to the many people who contributed to this study including Liliane Schmid, P. Schlup, B. Ribi. R. Illi. Dr. H. Bührer, Dr. P. Bossard. Dr. U. Uehlinger. We especially thank Beatrix Egli for the aecurate measurements and counts of the zooplankton. We are gratefut for the comments made on the manuseript by Prof. H. Ambühl. We would aiso like to thank Tony Mason for his technically conpetent translation of the manuscript.

\section{REFERENCES}

Anderson, R.St.: Predator-prey relationships and predation ratcs for crustacean zooplankters from some lakes in western Canada. Can. J. Zool. 48.12291240 (1970).

2 Bergunist, A.M., Carpenter, S.R., ind Latino, C.: Shills in phytoplinkton size structure and community composition during grazing by conirasting zooplankton assimblages. Limuol. Oceanogr. 30) (5), 1037 1045 (1985)

3 Bürgi, H. R., Bührer, H., Blocsch, J., und Szzbo. E.: Der Einfluss experimentell vatriierrer Zooplanktondichte auf dic Produktion und Sedimentation im hocheutrophen Sce. Schweiz. Z. Hydrol. 41, 38.63 (1979).

Bürgi. H. R.: Eine ncuc Netzgärnitur mit Kipp-Schliessmechanisnus für quantitative Zooplanktonfänge in Sien. Schweiz. Z. Hydrol. 45. 505 507 (1983).

5 Burns, C. W.: The relationship between body size of filter-feeding Clatlocera and the maximunn size of particle ingested. Limnol. Oceanngr. 13.675-678 (1968)

6 Dodson. A. N.. and Thomas, W. H.: Reverse filtration, In: Sournia, A. (ed.): Phytoplankton manual. p. $10-$ 107. Unesco, Paris (Monogr. oceinogr. Meth. 6) (1978)

7 Edmondson. W. T.: Reproductive rate of planktonic retifers as related to food and temperature in nature: Ecol. Monogr. 35, 61-111 (1965). 
8 Einsle. U.: Die äusseren Bedingungen der Diapause planktisch lebender Cyclops-Arten. Arch. Hydrobiol. 63, 387-403(1967).

9 Einslc, U.: Dic Entwicklung und Männchenbildung der Duphnia-Population im Bodensee-Ohersce 1956. 1980. Schwciz. Z. Hydrol. 45. 321 Män 332 (198.3).
19.8.

10 Gothen. M., Cavari, B. Z., and Berman, T. Zoophask kton feeding on differentially labelled algac and bacteria. Natlure 247, 393394 (1974).

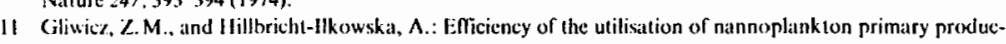
tion by communitics of fitter fecting animats neasered in site. Verh, int. Verein. Limnot. 18. 197 203 (1972).

12 Gitiwica. Z.M.: Fihkering rittes, food size seicction, and feeding rates in claduccrans - another aspect of interspecific competition in filter-feeding zooplankton. In: Kerfoot, W.Ch. (ed.): The evolution and ecology

13 Hadas, O., Cavari, B.Z., Kott, Y., and Bachrach. U.: Preferential foeding behavior of Daphima magna. Hydrobiologia 89, 49-52 (1982)

14 Infante. A.: Unlersuchungen über die Ausnutzbarkeit verschiedener Algen durch das Zooplankton. Arch.

5 Margakef, R.: Modelos fisicos simplificados de poblaciones de organismos. Mem. R. Acad. Cienc. Artes Barcelona 34, 81-146 (1962).

16 McNaught, D.C., Gricsmer, D., and Kennedy, M.: Resource characteristics modifying selective grazing by copepods. In: Kerfout, W.Ch. (ed.): The evolution and ecology of zooptankton communitics. University

17 Press of New England (1980). tersec. Schweiz. Z. Hydrol. 32, 90-149 (1970).

18 Muckie, R., and Dillmann-Vogel, H.: Die bisexuelle Fortplanzung in der Daphnia longispina-Gruppe des Bodensee-Obersees. Beitr. naturk. Forsch. SüdwDtl. 35, 81-94 (1976).

19 OECD: OECD Eutrophication Programme Regional Project Alpine Lakes (1980).

Porter, K.: Selective grazing and differential digestion of algac by zooplankton. Nature 244, 179-180 (1973).

Rott, E.: Some results from phytoplankton counting intercalibrations. Schweiz. Z. Hydrol. 43, 34-62 (1981).

Ruitner-Kolisko, A.: Rotatoria. in: Dic Binnengewasser, vol. 25, part l. Stutgart 1972.

24 Utr. 2, 1-38 (1958).

5 Vetter, H.: Bemerkungen über das Phytoplankton und seine Beziehungen zur Ernährung des Crustaceenplanktons im Schussenaltwasser und im Bühelweiher. Schr. Ver. Gesch. Bodensees 64 (1937).

Address of the authors: Limnological Department, EAWAG, Uberlandstrasse 133, CH-8690 Dübendorf, Switzerland. 